\title{
Taxing Multinationals: The Meat Myth and a Global, Ethical Tax
}

\author{
Anna Pellanda* \\ Professor of Political Economy (Retired), University of Padua, Italy \\ *Corresponding Author: Anna Pellanda, Professor of Political Economy (Retired), \\ University of Padua, Italy.
}

Received: July 05, 2021

Published: August 09, 2021

(C) All rights are reserved by Anna Pellanda.

\section{Abstract}

This contribution calls for the creation of a tax ${ }^{1}$ on meat coming from intensive farming. It draws on the novel "minimum global tax" on digital multinationals proposed in recent months by the American government, which has met with international approval as a way to deal with the problem of "tax havens" used to evade and avoid any fair taxation on these companies' enormous profits. The validity of this new tax is seen as deriving precisely from its global reach. In other words, it is designed to leave no loopholes, neither on the demand nor on the supply side. Such a globalized taxation is set against the tax competition between different countries that has been operating to date.

The great power of multinationals - be they in the digital or the meat industry - lies in a number of factors, one of which is their size (examined here in our comparison between the two sectors). Another fundamental element on which the multinationals leverage is consumer behavior, as studied by Duesenberry in his time. When it comes to meat consumption, this is where we see what J. Rifkin described as the myth about meat. A myth extremely harmful to human beings and the environment alike, given the very hazardous conditions in which animals in intensive breeding farms are fed and housed.

In devising a new tax on meat, it would be important to consider those already levied on cigarettes, sugar and carbon, which have revealed weaknesses that need to be avoided. An econometric analysis should be conducted to establish appropriate tax rates for different cuts and types of meat, and to calculate the prices at which it is sold in different countries. As these prices are currently kept very low (given the multinationals' production methods), the new tax should be global and high enough to prevent meat consumption from continuing to damage human health, the climate, and animal wellbeing.

Keywords: Taxing Meat Multinationals; Meat Production Methods; Damage Caused; Attainable Goals

\section{Introduction}

This contribution takes a comparative approach to the idea of taxing meat-producing multinationals. We begin by examining the proposed taxation of digital multinationals that, in recent months, has made some very important progress, strongly supported by Janet Yellen, United States Secretary of the Treasury. Her suggestion of a minimum global tax on digital multinationals has been shared by the World Bank, the OECD, the IMF, and the EU. The procedure for obtaining the necessary approval is expected to take a couple of years. The great novelty and validity of this proposed tax lie in its being global. This is very important because if the markets are global, then taxation must be global too. Otherwise there is no avoiding the tax competition that has always existed between different countries, and that multinationals exploit.

${ }^{1}$ The distinction between taxes, duties and levies is disregarded in this paper. 
A short section is dedicated here to comparing national tax competition with multinational globalization. Then we move on to consider the factors that multinationals can leverage on. Of all their constitutive elements, it is their huge size that interests us here. This is mainly because it is a feature that digital multinationals and meat-producing multinationals share in some ways, but not in others. Digital multinationals operate in space, while meat multinationals conduct their activities within confines that could hardly be more limited and physical - think of the tragically overcrowded conditions in which the animals are raised to make the most of the available space in intensive farming installations.

Such animal breeding methods are strongly rooted in consumer behavior. People have always seen meat eating as something for the elite; only the wealthy could afford it. Alongside the need for sufficient financial resources, as J. S. Duesenberry theorized, there were also social and psychological reasons for identifying meat consumption as distinctive of the envied well-to-do classes. This attitude stems from what J. Rifkin described as the myth about meat. It is so entrenched that nobody cares about the damage that meat eating causes to people's health, the environment and the animals involved.

The harm derives largely from what intensively-bred animals are fed. They are given plentiful quantities of growth hormones and antibiotics (to prevent infections), along with a diet of soy and cereals. Animal feed is needed in such quantities that growing it demands the destruction of whole forests, as we are witnessing in Brazil, the United States and elsewhere. The animals' digestive processes (especially in the case of cattle) then trigger the release of greenhouse gases, ammonia (a cause of acid rain) and contribute to the formation of airborne particulate matter. The damage thus extends from the suffering of the animals to humans, and from humans to the environment.

But people are utterly indifferent to this whole vicious cycle. In an effort to combat this situation, we propose a tax on meat. Here again, the approach is comparative: we consider this possible new tax vis-à-vis those already in force on passive smoking, sugar (in alcoholic beverages), and carbon (oil and gas). The adoption of these taxes varies from one country to another. While tobacco has been widely taxed, a levy on sugar has yet to be adopted in Italy, for instance, and carbon taxing has proved very difficult and controversial. All these taxes have their weaknesses: some can be evaded (as with contraband cigarettes); others have triggered very strong reactions or encouraged the relocation of industrial activities and created conditions of unfair competition.

Here we suggest that a tax on meat would need to be global to be effective, like the proposed tax on digital multinationals. It should not be at a minimum rate, however. It should be high enough to discourage people from eating meat, given all the harm it causes to human health and the environment, and also to make them less insensitive to the wellbeing of animals that are currently very badly mistreated. Econometric studies will be needed, but it is equally essential to induce a change of lifestyle and promote a greater respect for animal life. People's dietary habits need to move away from the horrors of intensive animal farming, which are unworthy of civilized human beings.

\section{Taxing digital multinationals}

Adam Smith's "invisible hand" has very obviously lost its ability to maintain a balanced market. This is partly because of a production that is, if not invisible, certainly impossible to trace. The digital industry does not manufacture physical items and its multinational organizations go to show that - in real life - the power of a monopoly is stronger than the power of competition. While Milton Friedman believed that competition could promote peace and freedom [1], if anything we are now in a situation where, while two great blocks like the USA and Europe quarrel, a third (China) rejoices. This enormous economic-political scourge was triggered by the Web Tax, which has brought to light how the enormous power of Silicon Valley has succeeded in creating the digital era and disseminating it around the world, making vast profits in the process. This has been facilitated by exploiting the tax breaks offered by some European countries, such as Ireland, the Netherlands and Luxembourg, Malta and Cyprus. These countries join forces in claiming that tax competition between nations is useful because it stimulates economic growth in the countries where companies move to benefit from lower tax rates. This is the front of the so-called positive externalities [2]. A while ago, these countries offered favorable conditions to the four American tech giants - Google, Apple, Facebook and Amazon (GAFA) - to attract the powers that be in the internet world. Then, when a handful of manufacturers of smartphones, computers and various other IT devices monopolized the global demand, Europe came to realize that it counted for very little on this world stage. 
A strong belief in the "laisser faire, laisser passer" attitude within the EU opened its doors to the Californian invasion without even identifying the technological "net product" to tax. Some European countries then belatedly sought to make up for lost time: on 29 September 2017 in Tallinn (Estonia), France, Germany Spain, and Italy proposed to tax GAFA, and take action to deal with their fiscal evasion and avoidance [3]. These countries claim that tax competition is harmful: it subtracts resources from the budgets of the countries where the companies involved operate, and induces governments to redistribute the fiscal burden from capital to workers. These countries form the front of the negative externalities, in opposition to the previously-mentioned front of the positive ones [4].

In actual fact, Italy had accused Apple of tax evasion already in 2015 and imposed a fine on the company on the strength of the concept of "stable organization" for its sales even in the absence of a stable physical presence. It was only in Tallinn, however, that a "systematic action" against the major players on the Web began to take shape. The American reaction was very determined: the US government defended its multinationals, based on the concept that they are American companies and any taxes levied in Europe would damage the US budget. Under the Trump presidency, there was even a threat of retaliation on European imports (such as motorcars from Germany, or agricultural products from France and Italy) if European countries were to insist on imposing taxes on the digital multinationals. The EU has now joined the international fray. The EU Internal Market Commissioner, Thierry Breton, and the Executive Vice President of the European Commission, Margrete Vestager, have proposed some revolutionary packages. One is the Digital Market Act (DMA) to combat the dominant position of GAFA; another is the Digital Service Act (DSA) against the illegal practices and content of their broadcasting. These measures are evidence in themselves of the multinationals' excessive power - not only in economic terms (with their enormous profits), but also on the moral stage, where they behave as if they were above the law (and fake news is just one example of this). Brussels aims to contain the multinationals' monopolistic behavior by imposing various sanctions regarding compulsory commercial services ("blacklisting"), data that are collected and not shared ("white listing"), and unnegotiated system interoperability ("gray listing"). If these rules are disregarded, the strongest punishment the EU can impose will be to dismantle the American monopolies in Europe. The EU will not be able to waive any of these sanctions, partly because they le- verage on the Web Tax to collect funds for the $€ 500$ billion in nonrepayable aid promised by the Recovery Act to help the countries most affected by the COVID-19 pandemic.

Unless some kind of agreement is reached, we will see a return to the typically ill-fated trade wars, which can easily give rise to actual wars too. Fortunately, the very authoritative voice of Janet Yellen, Secretary of the US Treasury under the Biden government, was heard in April 2021, when she advanced her idea of a "minimum global tax". This has come as a bolt of lightning in a far from blue sky because, even now that the Trump presidency is over, the United States remains unwilling to tax its multinationals and other companies. That said, we should not underestimate the fact that the new Biden administration had even gone so far as to suggest raising the corporate tax rate to $28 \%$. Now Janet Yellen aims to begin discussions with the OECD, IMF and World Bank on a scheme to tax multinationals in the countries where they make their profits - even if they have no physical presence there. She has suggested imposing a minimum global tax rate of $15 \%$. For the two types of tax (on companies and multinationals), there has much debate within the OECD and the UN on other possible rates, ranging from $12.5 \%$ to $20 \%$ and even $30 \%$. All these proposals go to show that this fiscal problem has become a hot topic internationally, with all the weight of its very burdensome consequences.

As regards multinationals, Yellen's proposal is to override national taxation policies and thereby eliminate the risk of trade wars, which have always put a strain on the countries involved. of course, tax competition between different countries can bring prices down, but globalization reduces them even more. It is to the combination of the two that we now turn our attention.

Tax competition between countries, multinational globalization and pricing systems

There is a great variety of literature on the topic of tax competition [5]. It is generally agreed that the concept describes a process by means of which national governments may choose to make their country more attractive to foreign economic investment by offering tax breaks [6] or favorable banking conditions (such as the banking secret [7] commonplace in Switzerland). The aim is to make a country more appealing to foreign manufacturers, or to discourage the transfer of domestic capital abroad. Inasmuch as concerns Europe, these practices rely on two main features, one historical- 
political dating back to the 1950s, the other operational-strategic and achieved by various measures.

The former consists in considering the tax competition phenomenon as related to Europe's evolution, culminating in the creation of the European Common Market, established by the Treaty of Rome in 1957, and implemented by the Maastricht Treaty in 1993. The EMC revolves around the so-called four freedoms of movement, or the free circulation of people, goods, services and capital. In particular, the freedom to move capital has facilitated the identification of countries where it is more economically convenient for companies to operate, encouraging these countries to further reduce their physical pressure on enterprises. This freedom of movement has been put to good use by tech companies that produce invisible goods, such as digital services. Tech giants have been able to exploit this lack of national boundaries to establish multinationals that now dominate global trade (the OECD calculates that they account for $60 \%$ ). Their organizations are based on mother companies (or holdings) in one country, and sister companies in many others.

The second theoretical feature concerns the competitive element of tax competition. According to Edwards and Keen [8], this element is handled in an uncooperative manner (we might say à la Cournot if there were only two parties involved), and it is very hard to tell what strategies different countries use to exploit their competitive advantage over others. The theory of the firm (that generated the first systematic theorization of competition) draws, in its most elaborate formulation, on game theory to delineate a strategic balance [9]. In the fiscal setting, what happens when countries do not cooperate is studied in terms of the Nash equilibrium [10]. Such analyses are highly theoretical, and discussing them here would take up too much space. Instead, we can reflect on the relationship between tax competition and globalization in an effort to identify the mechanisms used by large companies to operate in the real world.

Tax competition is a phenomenon tied to the national borders of single countries; and globalization and multinational enterprises can go beyond them, and exploit them particularly effectively. As Giuliano Amato put it, "the dilation of geographical markets" beyond national borders, and the increasingly invasive presence of multinationals weaken our ability to regulate competition because "none of the existing anti-trust authorities are capable of intervening, or of doing so adequately, as regards operations that go beyond their boundaries" [11]. Yellen's proposal of a minimum global tax seeks to overcome this difficulty: a globalized market calls for globalized taxation.

The fallout on prices reflects the problems involved. Competition, including tax competition, lowers the costs and consequent prices of goods and services. Preventing competition incurs rising prices, with immediate damaging effects on consumers. But consumers can currently overcome this problem by resorting to foreign markets. Taxing the major multinationals globally would mean giving consumers no chance to purchase goods and services anywhere, wherever they might find lower prices. Here lies the great value of Yellen's proposal: digital multinationals should be taxed everywhere, at the same rate, wherever they operate and wherever they sell their wares.

One of the strengths of multinationals lies in that they are able to exploit the different fiscal regimes of different countries. In fact, they not only increase their production capacity thanks to the enormous capital they accrue, but also adopt all the latest technologies to exploit economies of scale. They manipulate the elasticity of the demand, but also benefit from the tax breaks offered them by obliging countries. Digital multinationals use very astute fiscal strategies (and so do multinationals in the food sector [12], of particular interest to us here), the most complex of which is called "double non-taxation". This involves evading the taxes levied by the country where their production site is located (and where added value is created), and avoiding the taxes due in the country to which they have moved their business (far from their country of origin). Tax competition is therefore very useful to multinationals, while a global tax on their profits could not fail to reach them. It is consequently easy to understand why the idea of taxing them is vehemently opposed not only by the multinationals, but also by consumers who benefit from the low prices deriving from the multinationals' "tax savings".

\section{The dimension of multinationals}

In the light of the above considerations, it is obvious why multinationals gain the favor of consumers, and the support of their country of origin: the former are interested in the low prices they charge; the latter in the economic and political prestige they afford. 
Multinationals can sell their products all over the world at impossibly low prices, and digital multinationals are the most shocking example of this. Computers and smartphones are constantly performing better and better, at accessible prices everywhere. People who possess these products not only obtain something very useful for work and play, but also exhibit their social status. Doing without them is unthinkable, and many people are continually striving to own the latest model to show off. This consumerist process ensures that the elasticity of the demand and the supplier's profits stay high.

The GAFA oligopoly shrinks in horror from the concept of perfect elasticity of demand ( $\mathrm{ed} \rightarrow \infty$ ) that low prices in a state of perfect competition can engender. Of this two-way balance between prices and elasticity, it retains the low prices, but comes to bear on the trend of the demand curve to keep it at an elasticity of $>1$. The promotion through advertising pursued by the multinationals with a great profusion of means is designed specifically to ensure that the urge to purchase the latest models of their products remains strong. The meat-producing multinationals are particularly interested in their version of this phenomenon (the so-called meat myth), as discussed later on. The GAFA oligopoly relies on all the tools typical of the great monopolies: the previously-mentioned sales pitch in their advertising, technological progress, huge dimensions, patents, and legal and fiscal concessions.

This is clearly a dynamic, long-term state in which all costs can be seen as variable, thanks primarily to technological progress that, adopted with the necessary foresight, increases the productivity of the multinationals' physical and human capital (in fact, the people handling sophisticated machinery must be increasingly qualified). The variability (or downward trend) of their costs over time is also supported by the companies' very large dimensions and economies of scale. Because of their small size, smaller enterprises cannot escape the effects of rising marginal and mean costs, as demonstrated by a normal "envelope curve". To cope with increasing costs, firms have to grow larger in order to distribute them over larger quantities of products. This is the strategy adopted by multinationals operating on the world markets. The importance of being big was not discovered by the multinationals, however. Already in 1959, it had been theorized by Edith Penrose in her most famous work [13]. She said that, if a dynamic firm wishes to expand over the long term, it must attract its rivals' customers by offering lower prices, shoulder the costs of research and advertising, and even waive its own profits in the short term. Maximizing profits, as businesses typically do in the short term, is no good in the long term, when it is "the very expansion of the business that becomes a necessary condition to enable further expansion", as Graziani put it [14]. Digital multinationals are a demonstration of this theory and meat-producing multinationals confirm it in tragically physical terms.

Meat multinationals have industrial-scale installations that consist of sheds, each usually $15 \mathrm{~m}$ wide, $40 \mathrm{~m}$ long, and $7 \mathrm{~m}$ high, with a corridor $1 \mathrm{~m}$ wide. Intensive breeding farms always have numerous sheds (the largest number documented so far in a well-known photograph by Sans Soleil was 22). Their metric dimensions tell us little, however, about how the space inside the sheds is exploited. Inside, huge numbers of animals are crowded together, be they pigs, cattle, chickens, rabbits, or fish in huge tanks. There can be $17-$ 22 chickens per square meter. Pigs live in metal cages $60 \mathrm{~cm}$ wide, 2 $\mathrm{m}$ long, and $65 \mathrm{~cm}$ high, where they are unable to move even when they give birth to piglets (which often die trampled under the sow's feet). Cows and their calves are kept in cages only slightly larger than their own bodies. Rabbits are held in pairs, in cages $20 \times 35 \mathrm{~cm}$ in size, and 30-35 cm high. Fish are bred in huge tanks containing so many of them that they are unable to swim; they can only harm themselves against the sides of the tank (if they ever reach them).

While the products of digital multinationals move in an unbound space, the boundaries of the meat-producing multinationals' installations are extremely physical, so they make the most of the space available. In doing so [15], they condemn the animals to a life of hardship, filth, and deprivations of all kinds. In adopting these cruel breeding conditions, the multinationals have calculated their real and monetary internal economies with no regard whatsoever for the real diseconomies caused by the animals' suffering, and the hazards inherent in their approach. It is common knowledge that raising animals in such overcrowded conditions in order to produce more and more meat at the lowest possible prices is a source of harm to human health and environmental pollution. The latest pandemic caused by COVID-19 (now known to be of zoonotic origin) prompted Denmark to kill 17 million mink at breeding farms around the country because some of them had tested positive to a mutation of the coronavirus. This action was imitated by other countries too (source Dagbladet Holstebro-Struer). But such events are just the tip of the iceberg of a terribly inhumane produc- 
tion system that is also profoundly harmful to mankind and to the planet. Reflecting on what has led to this social disaster for exclusively economic goals brings us to the topic of the myth about meat eating.

\section{The meat myth}

Analyses by the classic economics authors emphasized the importance of supply to such a degree that, in 1803, Say's "law of outlets" even claimed that it is the supply that creates the demand. With marginalism, demand came to be acknowledged a founding role in the creation of value, and then the neoclassical approach established that consumers are sovereign and rational, and their demand decreases with their decreasing marginal utility. Already in 1883, however, with Giffen, there came a breach in this logic (albeit limited to particular cases) when the price of meat and of the "most costly starchy foods" rose enough to make them inaccessible to the "working classes". The decreasing trend of the demand curve is paradoxically reversed in such cases, replaced by an increasing trend. The separation between consumption and (marginal) utility only becomes decisive with Keynes, however, who unequivocally states that the demand depends on the consumers' income.

This brief historical excursus goes to show that consumption was studied using measurable variables. Then, in 1944, the American economist Duesenberry [16] used non-economic motives to explain that it is individuals' psychological features and the influence of society that drive consumer behavior and demand. Duesenberry acknowledges that his ideas were inspired by Thorstein Veblen (author of The Theory of the Leisure Class [1899]), and Frank H. Knight (author of The Ethics of Competition [1921]). In the present paper, we leverage on Duesenberry's theory in an effort to explain why the demand for meat on the part of today's consumers is so strongly tied to private ambition and social influence rather than to any neoclassical sovereign and rational consumer behavior.

Duesenberry retains Keynes's assumption that consumption depends on income $[\mathrm{C}(\mathrm{Y})]$ but enriches it with the temporal dynamics of present and past income, calling this new concept "relative income". He makes the point that habits of consumption formed on the basis of past income have to be modified if the consumer's present income changes. If our present income is lower than in the past, we can maintain our previous habits of consumption only by resorting to our savings (if we have any) or loans or getting into debt. Our attachment to a certain type of consumption is due to the fact that people purchase certain goods because of the social prestige that derives from imitating other people's lifestyles. An individual's self-confidence may come to depend on the amount of income they can spend on increasingly-qualified consumer goods of the kind bought by others who have a higher standard of living. This is the "demonstration effect" founded on drawing comparisons with others, and on the social achievements people want to flaunt. Duesenberry makes the point that social classes have been replaced by a mobility relating to people's relative income and demonstrable consumption. Meat is one of the qualified consumer goods that demonstrate our social status. We briefly outline below how meat consumption, and the associated human gluttony, have historically been interpreted as a sign of social standing.

The issue of food is much more complicated than it might seem. It has ethnic, social and cultural facets, as well as cogent economic constraints. Meat consumption is affected by all these aspects and, as regards the European area, we can say that it occurs over a whole spectrum that ranges from subsistence to prestige. The powerful classes have always seen meat as a mark of distinction. In Ancient Greece, humans shared it with the Gods. In Ancient Rome, it was the centerpiece of the sumptuous banquets of the rich [17]. The lower classes (and the slaves, of course) were always strictly excluded from such events. In the Middle Ages, they were barred from even participating in their feudal lords' hunting trips, at a time when game meat was much preferred to beef (cattle were too laborious to breed). Then, with the Renaissance came refinements in the ways in which meat was cooked (instead of just roasting it over the wood fire as in the past).

Over the centuries, the lower classes lived largely on a diet of cereals and pulses, and - after the discovery of the Americas (and after their initial diffidence had been overcome) - potatoes. In the Great Famine of 1845 in Ireland, when a poisonous fungus destroyed all the potatoes, much of the population (half a million people) died of starvation because there was nothing else to eat. With the Industrial Revolution, the population moved from the country into the cities and their eating habits gradually changed. But in all this time, for centuries, eating for the lower classes was about survival, while for the upper classes it was a way of flaunting power. In analyzing this situation, Rifkin [18] speaks about the British people's "obsession with meat", and emphasizes how the UK's poor would constantly dream of eating meat like the aristocracy. 
What was once a question of survival is today a matter of fashion. Consumers who buy no meat are seen as second- or even thirdclass citizens, and the world of intensive animal farming leverages on this old idea of their social inferiority inherited from the past. Today's consumption levels confirm that meat, though still an item of social prestige, is hardly a luxury. The very astute strategies of the multinationals have made sure it is sustainable for them to keep the prices low. Information campaigns about the damage meat consumption causes to human health and the environment have little effect - and any mention of the suffering inflicted on the animals concerned has even less. Beef consumption has been declining slightly in recent years, but the same cannot be said for chicken or fish [19]. The idea of social distinction associated with eating meat has become a habit that is hard to break [20]. It is gluttony cloaked in the recipes of famous chefs, and promoted by ill-informed dietologists who exalt its consumption all to the benefit of the multinationals. Consumers are either ignorant or indifferent: they absorb these partisan promotional influences and satisfy their greediness. But, like all myths, the meat myth - with all the social prestige and consumerist greediness attached to it - will ultimately meet its end in the growing awareness of more responsible consumers.

\section{The damage caused by eating meat}

The myth about meat is not like those surrounding sophisticated digital equipment, stately homes, luxury clothes, and the like, which are designed to demonstrate an individual's social status. Such luxury goods do little to harm either the person concerned or the environment. Eating meat, on the other hand, causes human diseases and pollutes the environment, as well as causing immense suffering for the animals bred as consumer food products.

For some time now, international organizations interested in the problem (and especially the WHO and FAO) and numerous associations have been denouncing the harm that meat consumption causes to human health. The reasons lie primarily in the very hazardous diet on which the animals are fed: a mixture of soy, cereals, hormones and antibiotics. Hormones are used to fatten the animals and speed up their growth, in order to sell them young and plump. Antibiotics (with more than $70 \%$ of the world's consumption going to the 70 billion animals bred for food) are needed to avoid the animals becoming ill as a result of living in overcrowded, unhealthy conditions. But bacteria defend themselves, becoming increasingly resistant, and constantly obliging breeders to use more and more of these drugs. As they are not excreted in the animals' droppings, these antibiotics pass into their flesh, and consequently onto the plates of human beings. Eating meat, and especially red and processed meat (in Italy, its consumption amounts to around $128 \mathrm{~g}$ per capita daily for more than $90 \%$ of the population), not only raises people's antibiotic resistance, but also causes diseases such as diabetes mellitus type II, stroke, and colorectal cancer [21].

The soy used to feed animals in intensive breeding farms comes largely (80\%) from Argentina, Brazil, and the United States. To produce enough of it, deforestation is proceeding at a frenetic pace in Amazonia, and the Cerrado [22], but also in Europe [23], and elsewhere. This deforestation is one of the most depressing and harmful types of environmental pollution induced by meat production and consumption. The vegetation and soil of these regions in Brazil, which are constantly being stolen from the indigenous people (the area's legitimate inhabitants) could absorb 13.7 billion tons of $\mathrm{CO}_{2} \mathrm{a}$ year. In addition to deforestation, other damage to the environment deriving from the intensive animal breeding farms includes the emissions from the animals themselves. These enormous agglomerations of animals release greenhouse gases that account for $17 \%$ of the total emissions of all the motor vehicles in the EU, and $24 \%$ of global emissions [24]. The combination of deforestation and greenhouse gases is inexorably raising the temperature of the planet. In addition, the animals' droppings are no longer disposed of as they used to be (by spreading them over the fields). They are carried on huge conveyor belts outside the intensive farms and amassed, polluting the water table, rivers and sea, acidifying the water with the nitrogen and ammonia they contain. The ammonia coming from animal droppings is released into the air and takes part in producing airborne particulate matter (PM 2.5). The adequate treatment of wastewater from intensive breeding farms would demand huge attention to water purification, which is obviously costly - but human beings will continue to fall prey to pandemics if it is not done properly. The connection between air pollution and the propagation of the SARS-CoV-2 virus is currently being studied by researchers at the Harvard and Johns Hopkins Universities.

While these types of damage caused by intensive breeding farms affect humans and the environment, they are minimal compared with the suffering caused to the animals themselves. It is hard to imagine what happens at these installations unless we see for ourselves - and gaining access to them is difficult. One of the 
first people to do so was Jonathan S. Foer, who published a book in 2009 [25] with a merciless account of the atrocities that take place at these farms. The barbaric way in which the animals are kept without enough air, space to move, proper food, or any semblance of a natural life - is made even worse by the sadistic behavior of people working at these places, and involved in transporting live animals to the slaughterhouse, and in the uncivilized, but legally permitted and uncontrolled methods used to kill them. Before Foer wrote about them, these conditions were kept well hidden by the producers of meat, fish and eggs (not to mention the breeders of animals for fur). With time, worthy animal rights associations and brave volunteers, intellectuals and artists have begun to raise the alarm and inform the public about what producers and retailers, and their powerful lobbies, have been trying to keep under wraps. The fact is that, ever since intensive farming was invented [26], these installations have always been places where animals are tortured, as Philip Lymbery of the CIWF made clear [27]. Consumers, with all their previously-mentioned weaknesses, tacitly support this appalling behavior unworthy of human beings.

If not even our fear of contracting serious diseases from eating meat, or our concern for the environment can move our collective conscience, then tax policies are needed. It was Pigou who said that, if companies do not acknowledge the deleterious effects of their operations on the environment, and do not shoulder the social costs of the external diseconomies they trigger, then governments must intervene to force their hand [28]. Here we are describing just such a situation: if meat producers and consumers do not admit to the damage to mankind, the environment and the animals that producing and consuming meat causes, then they should be taxed. Hopefully, this would be seen not as a case of "giving to Caesar what is Caesar's" [29], but rather of putting a brake on the greediness of producers and the gluttony of consumers.

\section{A tax that is global and ethical}

There is an undeniably ethical connotation invoked here, that tax policies can certainly adopt - as done on other occasions. What reasons could Italy possibly have had for taxing tobacco (the sale of which was under a state monopoly), other than to protect the health of smokers and non-smokers? The same applies to proposed taxes on sugar, which would be designed to combat obesity in childhood (caused by soft drinks) and alcohol-associated diseases in adults. Only the "Carbon Tax" has a dual goal: to protect the health of the population and to safeguard the environment. In the hope of learning from the fiscal experiences previously discussed and/or implemented in these other sectors, it is worth noting some similarities with our present case.

After various decrees and regulations, the "Sirchia law" was passed in Italy (n.3, art. 51) in 2003 to "safeguard the health of nonsmokers". It was subsequently completed with further restrictions and rules by means of which the State aimed to protect against passive smoking, but also to reduce the harm caused by active smoking, which accounted in Italy alone for 70,000 deaths a year. Every law has its loopholes, however, and the government's actions prompted a revitalization of the black market for cigarettes. So, if we consider taxing meat, then to avoid meat-eating consumers purchasing it illegally, this tax should be global - just like the one proposed on the products of the digital multinationals. If we really want to rid ourselves of an evil, we cannot leave any escape routes open.

From taxation on sugary soft drinks, there is unfortunately little to be learned because (in Italy, at least) it has proved impossible to impose. Much the same can be said of almost all the American States, whereas several countries in Europe have adopted such a measure, albeit with considerable differences in their approaches. The WHO has suggested that, for such a tax to be really effective, it should amount to $20 \%$ of the retail price of the drink. This can be taken as a valid reference if we want to combat obesity (especially in children), and possibly also diabetes and gout. In Italy there have been too many ministries having their say on the issue (including the Ministry of Public Health, the Ministry for Development, and the Ministry for Agricultural Policies), whereas - to be effective such an initiative needs to be decisive and cohesive. The problem is partly due to the industrial lobbies in this sector meddling effectively in the relations between the world of medical-scientific research and that of mass production to prevent them from cooperating. The meat-producing lobbies would do the same, and far more, to counter the introduction of a meat tax, and this needs to be borne in mind.

Experience gained with the carbon tax adopted to discourage the use of coal, oil and gas, and to promote the use of renewable energy sources is rather more encouraging. As documented by the World Bank [30], 46 countries have adopted this tax since the worthy Scandinavian democracies took action in this sense in the early 
1990s. The great debate nowadays is between the more virtuous countries (led by Germany) and the great polluters (like the United States, China, India and Brazil). The Nobel prizewinner for economics, Professor Nordhaus, has made it clear that we have to switch to the use of renewable sources if we want to save the environment. In a sense, the reasoning is similar for the tax on meat: we have to encourage consumers to shift to a meat-free diet and producers to invest in producing crops instead of livestock. $\mathrm{CO}_{2}$ emissions could serve as a logical link between the carbon tax and the proposed meat tax: both arouse a very strong "tax aversion", and both will be the object of unfair competition and delocalization unless they are applied globally.

In the light of the above considerations, it is clear that the idea of a minimum global tax on the digital multinationals is the best, most complete model to adopt. Being global, it makes contraband unworthwhile; relying on a unanimous acceptance by all countries, it is effective against the lobbies, and makes delocalization pointless. But, as concerns Europe, it seems that the first wall to break down is Europe itself, or rather the European Parliament. At a meeting on Common Agricultural Policy (CAP or PAC) of 14 February 2019 , this institution fundamental to the EU's functioning voted to spend approximately $70-80 \%$ of the available funds theoretically destined for agriculture in general (a figure amounting to between $€ 28.5$ and $€ 32.6$ billion annually, or $18-20 \%$ of the total EU budget) on breeders that do not exceed certain dimensions, and that respect the basic principles of animal wellbeing. The immediately-raised obvious criticism [31] was that the number of breeders counts for nothing if the number of animals being raised, and the appalling conditions of intensive animal farms remain as before. It would seem that, as the Italian saying goes, they wish to change everything so that everything stays the same.

But if we want to protect human health, combat climate change, and pay attention to animal welfare, we need to take action - and taxation is a very powerful weapon. The theory here is that we need to introduce a global (non-)minimum tax on meat coming from intensive farming, drawing on the model of the proposed tax on the products of digital multinationals.

Though somewhat different, the proposal is not new. It has an illustrious scientific forerunner in a study conducted at Oxford University and published in the journal Public Library of Science
ONE in November 2018. The study suggested a tax to reduce the diseases related to meat consumption that were costing the world $\$ 285$ billion a year, and to limit the number of related deaths, estimated to be as high as 220,000 . The tax rate proposed was approximately $20 \%$ on unprocessed red meat (steak) and $110 \%$ on the more harmful processed meats (cold cuts). The revenue obtainable worldwide would amount to $\$ 170$ billion, to be spent on treatments for the diseases caused by an excessive meat consumption. Each country should calculate its percentage on the basis of its population's consumption and the costs to its public health systems. For this purpose, 149 different tax rates were calculated for the various countries, which were very high for the United States (with its huge meat consumption), and very low for countries in the developing world. If daily meat consumption were to diminish to one portion a day, the consumption of red meat would drop by $16 \%$.

It is not only scholars who have been concerned with the problem. Governments in countries like Germany, Sweden and Denmark have also considered taxing red meat. In 2016, the Danish estimated that a tax of $€ 2$ per kilo on beef would bring its consumption down by $14 \%$ and reduce the related greenhouse gas emissions by 20-35\%. The proposal was blocked by the Danish breeders, who feared any decline in people's meat eating. The same thing happened in Italy: as soon as the Coldiretti and Confederazione Agricola e Agroalimentare (AGRI) heard of a proposed tax on meat, they promptly retaliated by saying that it is people's unbalanced diets, not meat products in themselves, that are harmful. They also underscored the superiority of Italian meats because they come from animals that are not treated with hormones (unlike those of countries like the States) [32].

In a way, these events add value to the present proposal for a meat tax, but here we go a step further. All the above-mentioned scientific and political-operational investigations demonstrate a very practical focus: there is a product that we now know is harmful to humans and the environment, and something must be done to contain the damage it causes. This goes to show that the concern for human beings and the environment in which they live shifts very little from the traditional anthropocentrism of human reflection. It fails to see that humans are also damaging their own health and their own environment with their dreadful intensive breeding farms and terrible exploitation of the natural world. We refuse to 
accept that we ourselves are the executioners, not the victims, and even when we do begin to acknowledge our responsibility, we take a limited approach to damage control. There might be a tax on their steak or sausage, but people do not understand that they need to change their eating habits. They need to change their relationship with animals. A tax on meat should serve not just to reduce the consumption of harmful products and shift resources from private excesses to public goals. It should make us reflect on the horrors of "wet markets" and the pandemics they can trigger. It is the human desire to eat animals, and the greenhouse gases and airborne particulate matter deriving from intensive breeding that will backfire against mankind and his environment. Humans are not the owners of the universe, entitled to kill animals and ruin the environment to satisfy their voracious appetites, provide convenient transportation, heating, and so on. By giving up eating animals we acknowledge the equal dignity of creatures with which we have a bond of kinship [33], and by switching to a vegan diet we restore value to natural (not chemical) farming methods that neither pollute the environment nor poison us. This means moving/returning to a culture suited to our times and to a genuinely human, civilized way of life.

\section{Conclusion}

The proposal advanced here for a global non-minimum tax on meat is inspired by the global minimum tax on digital multinationals discussed in recent months by the American government, which has met with international approval. But while the digital multinationals should be taxed because they subtract resources from the countries where they operate, taxing meat multinationals would mean reducing the damage they cause. These include: (1) the harm to human health due to the diet fed to animals in intensive farms (the drugs it contains and the boundless deforestation needed to provide the feed); and (2) the pollution of the environment caused by the animals' gas emissions and droppings, which give rise to greenhouse gases, acid rain and airborne particulate matter.

Unless we can activate people's sense of responsibility and make them realize the need for change, we must resort to taxation - as done before as a way of combating (passive) smoking, excessive sugar consumption (from soft drinks), the use of fossil fuels, and so on. A sizable global tax on meat, as proposed here, would have the great goal of preventing human diseases, the pollution of the planet, and the suffering of animals, which must absolutely stop because it is unworthy of human civilization.

\section{Bibliography}

1. Friedman M. Capitalism and Freedom, Chicago, Chicago University Press (1962).

2. Zodrow GR. "Tax competition and tax coordination in EU". International Tax and Public Finance 10.6 (2003): 651-671.

3. Pellanda A. "Multinationals: the role of consumers and a new European fiscal trend". in: Paganetto, L., Yearning for Inclusive Growth and Development, Good Jobs and Sustainability, FUET, Economic Foundation, University of Rome Tor Vergata, Springer, (2019): 203-214.

4. Sokol N. "Corporate tax systems and tax competition in EU new Member States". Zagreb International Review of Economics and Business 11.2 (2008): 81-94.

5. Wilson JD "Theories of tax competition". National Tax Journal 52 (1999): 269-304. Boria P. "La concorrenza fiscale tra stati" , Padova, Cedam (2019).

6. Bordignon, M. - Empoli, D., ed. “Concorrenza fiscale in un' economia internazionale”. Milano, F. Angeli (1999).

7. D’Alfonso G. "Vantaggi e svantaggi della concorrenza fiscale internazionale". Il Fisco 25 (2005): 6.

8. Edwards J and Keen M. "Tax competition and Leviathan”. European Economic Review 1 (1996): 1131-1134.

9. Morgenstern, O. - Neumann, J. "Theory of Games and Economic Behavior". Princeton University Press (1944).

10. Wildasin DE. "Nash equilibrium in models of fiscal competition". Journal of Public Economics 2 (1988): 229-240.

11. Amato G. "Il potere e l'antitrust" , Bologna, Il Mulino (1998): 118.

12. The most famous American multinationals in the food sector are the "ten sisters" (a term borrowed from the "seven sisters" in the oil industry): Associated British Food (ABF), Coca Cola, Danone, General Mills, Kellogg's, Kraft (partly renamed Mondelez), Mars, Nestlè, Persico, and Unilever.

13. PENROSE E. The Theory of the Growth of the Firm (1959), Oxford University Press, 3rd ed. with a new Foreword by the A (1995).

14. Graziani A. "Teoria economica". Prezzi e distribuzione, Napoli, ESI, 3rd ed. (1993): 649. 
15. China has taken the intensive use of space to a new level, building farming installations for pigs (called "hotels") that extend vertically over several stores, to save space. The privately-run Guangxi Yangxiang farm in Southern China is building one 13 stores high (due to be the tallest in the world), where the animals will be moved using lifts. It is expected to contain 30,000 female pigs in 11 hectares (source "Reuters").

16. Duesenberry JS. "Income, Saving and the Theory of Consumer Behavior", Cambridge, Harvard University Press (1949).

17. The account of the dinner prepared by Trimalchio (a freedman who became rich), described by Petronius in his Satyricon (1st century AD), is an example of how important food can be to social climbing.

18. Rifkin J. Beyond Beef: the Rise and Fall of the Cattle Culture, E.P. Dutton and Co., (1992).

19. The European Commission has estimated that beef production dropped by $1.7 \%$, and its consumption by $2.7 \%$ in 2020 . In Italy, there is expected to be a $20 \%$ drop in the consumption of beef by 2030 , a $7.8 \%$ drop for pork, but a 3-4\% rise for poultry (ISTAT data) and a $\%$ increase for fish (ASSOITTICA data).

20. Already in the 1st century AD, Plutarch wrote that it was not easy to make people abandon their bad habits and, although man is not naturally carnivorous - since "he has no hooked beak or sharp nails or jagged teeth, no strong stomach" - he cultivates his appetite for dead animals by "smothering with countless condiments the taste of gore so that the palate may be deceived and accept what is foreign to it"; PLUTARCH, On the Eating of Flesh (my translation from PLUTARCO, Sul mangiar carne, Ed. G. Ditadi, Torino, AgireOra Edizioni (2016): 82, 71, 72-77.

21. "L'insostenibile impatto della carne in Italia". Il fatto quotidiano, 10.03.2021; "L'insostenibile costo della carne". demetra. net., 15.03.2021; “I costi nascosti della carne”. LAV, 08.05.2021. The debate on these topics is hotting up and occupying more and more space, not only in the specialist journals (like NATURE Sustainaibility, NATURE Genetics, etc.), but also in the mainstream media.

22. In the Cerrado, the second Brazilian biome after Amazonia, more than $800 \mathrm{~km} 2$ of forest have been destroyed to make space for breeding farms, and more than 12,000 forest fires have been started since 2015 (source AgireOraEdizioni).

23. Now approximately $71 \%$ of all farmland in the EU is used to produce animal feed.

24. Newsletter of the Fondazione CMCC dated 16/02/21.

25. FOER JS. Eating Animals, Little, Brown and Company (2009).
26. Intensive breeding farms started almost by accident in 1923 in Delmarva (Delaware) when Celia Steele ordered 50 chicks for her chicken coop (which contained about 23 animals), but she was sent 500 by mistake. She succeeded in keeping them all alive by using food supplements. Three years later she had 10,000 , and by 1935 she had 250,000 chickens.

27. Lymbery P and Oakeshoot I. Farmageddon. The True Cost of Cheap Meat, London, Bloomsbury Publishing (2014).

28. PIGOU AC. Economics of Welfare, London, Macmillan and Co., (1920).

29. St. PAUL, Letter to the Romans 13: 5-6.

30. https://carbonpricingdashboard.worldbank.org

31. Greepeace Dossier "Soldi pubblici in pasto agli allevamenti intensivi". $\quad$ https://storage.googleapis.com/planet4-italystateless/2019/02/47c7205a-report soldi in pasto. See also u=https://www.agireora.org/vegan/soldi-regaliamo-allevatori-3195.html The missing JEL Classification is : H 26

32. They could be placated by suggesting that the revenue coming from the meat tax, after its approval, could be used to support breeders who switch to farming plant crops instead - an idea worth examining in the future.

33. In 316-315 BC, Theophrastus concluded his essay "On Piety" by saying: "Similarly, we believe that all men, but all animals too, are of the same original stock because the first principles (archai) of their bodies are by nature the same ... and even more because the soul that is in them is no different in nature as regards their appetites, their fits of rage, their reasoning (logismoi) and, above all, their sensations. Like their bodies, some animals have a more or less perfect soul; but for all living beings the principles are by nature the same. The kinship of their affections is proof of this" (my translation from TEOFRASTO, Della Pietà, a cura di G. Ditadi, Este (PD), Isonomia (2005): 261263.

\section{Volume 5 Issue 9 September 2021 (C) All rights are reserved by Anna Pellanda.}

